\title{
High Prevalence of Hepatitis B Virus Infection Compared to Human Immunodeficiency Virus among Blood Donors in Bangui
}

\author{
Serges Magloire Camengo Police ${ }^{1 *}$, Bernard Bessanguem¹, Eveline Mofini' ${ }^{1}$, Benoît Elowa ${ }^{1}$, \\ Georges Service ${ }^{2}$, Peggy Guéréndo ${ }^{3}$, Armelo Thibaut Yangba Kalebanga1, \\ Nathalie Philomène Boua-Akélélo ${ }^{1}$, Tolmbaye Sem Fiacre Odilon ${ }^{1}$, Joseph Roger Molowa Kobendo ${ }^{1}$ \\ ${ }^{1}$ Department of Hepatogastroenterology and Internal Medicine of “Amitié Sino-Centrafraine”, University Hospital Center, \\ Bangui, Central African Republic \\ ${ }^{2}$ Department of Internal Medicine "Maman Elisabeth Domitien”, University Hospital Center, Bimbo, Central African Republic \\ ${ }^{3}$ Department of Venerology Dermatology, National University Hospital Center, Bangui, Central African Republic \\ Email: *camengop@netcourrier.com, servicegeorges@yahoo.fr, benoitelowa@gmail.com, pguerendo@yahoo.com, \\ yangbaarmelo@gmail.com, nathakel@yahoo.fr, emofini@yahoo.com, bernardbessan@gmail.com, tolmbayesem@yahoo.fr, \\ josephrogermolowak@yahoo.fr
}

How to cite this paper: Police, S.M.C. Bessanguem, B., Mofini, E., Elowa, B., Service, G., Guéréndo, P., Kalebanga, A.T.Y., Boua-Akélélo, N.P., Odilon, T.S.F. and Kobendo, J.R.M. (2020) High Prevalence of Hepatitis B Virus Infection Compared to Human Immunodeficiency Virus among Blood Donors in Bangui. Open Journal of Gastroenterology, 10, 137-143.

https://doi.org/10.4236/ojgas.2020.106014

Received: April 29, 2020

Accepted: June 1, 2020

Published: June 4, 2020

Copyright $(92020$ by author(s) and Scientific Research Publishing Inc. This work is licensed under the Creative Commons Attribution International License (CC BY 4.0).

http://creativecommons.org/licenses/by/4.0/

(c) (i) Open Access

\begin{abstract}
Introduction: Hepatitis B Virus (HBV) and Human Immunodeficiency Virus (HIV) infection is a public health problem worldwide, particularly in sub-Saharan Africa. Objective: to compare the epidemiological, clinical and biological characteristics of chronic HBV and HIV infection in blood donors at the National Center for Blood Transfusion (NCBT) in Bangui. Patients and Methods: This was an 8-month analytical cross-sectional study from August 10, 2011 to April 9, 2012. During this study, we consecutively enrolled consenting blood donors of both sexes in which the search for HBsAg and HIV infection was carried out. Results: During the study period, 850 blood donors were collected. HBsAg was found in 142 donors (16.7\%), of whom 55 blood donors (6.5\%) were coinfected with HIV. On the other hand, HIV serology was positive in 77 blood donors (9.1\%) including 55 co-infected (6.5\%) with HBV. In order to better compare the risk factors, we have not included HIV-HBV coinfected patients. Only 795 blood donors were selected for the risk factor study. There were 87 cases of HBsAg positive (10.9\%) and 22 cases of HIV positive (2.8\%). The average age of HIV and HBV infected patients was 25.7 and 26.2 years, respectively. Twelve blood donors (1.5\%) over the age of 20 were HBsAg versus 3 HIV positive blood donors (0.4\%). Among blood donors over the age of 20 , 75 (9.9\%) were HBsAg positive, while 19 (2.4\%) were HIV positive. Men were infected with HIV in 20 cases $(2.5 \%)$, while those infected with HBV were 84
\end{abstract}


(10.6\%). The risk factor found during HIV infection and HBV was unprotected sex with a p of 0.0038 and 0.0017 respectively. Conclusion: The prevalence of HBV infection is higher than that of HIV among blood donors in Bangui. The setting up of a national viral hepatitis control program, which will develop screening, treatment and vaccination actions could make the curve bend.

\section{Keywords}

Hepatitis B Virus Infection, HIV, Blood Donors, Bangui

\section{Introduction}

Hepatitis B Virus (HBV) infection and Human Immunodeficiency Virus (HIV) infection are a major public health problem worldwide. The World Health Organization (WHO) estimates in 2017 that 325 million people worldwide are living with chronic infection with HBV or the hepatitis C virus (HCV) [1]. Meanwhile, 37.9 million people worldwide were infected with HIV at the end of 2018, 25.7 million of whom are in Africa [2]. In 2015, viral hepatitis was responsible for 1.34 million deaths [1], while HIV infection was responsible for 770,000 deaths in 2018 worldwide [2]. In the Central African Republic, the prevalence of HBV infection varies from 10.6 to 19.8 depending on the study population [3] [4] [5] [6], while the prevalence of HIV infection is 4\% [7]. These are two viruses that share the same modes of transmission. Blood remains the potential source of transmission of HBV and HIV. This is why it is important and essential to look for these two viruses apart from other infections in blood donors, in order to guarantee transfusion safety. Our objective was to compare the epidemiological characteristics of blood donors infected with HBV with those infected with HIV at the National Center for Blood Transfusion (NCBT) in Bangui.

\section{Patients and Methods}

We conducted an 8-month cross-sectional analytical study from August 10, 2011 to April 9, 2012. We included in the study, consenting blood donors of two sexes in which the search for HBsAg and HIV were performed. Hepatitis B serology consisted in the search for $\mathrm{HBsAg}$ using the Monolisa $\mathrm{HBsAg}^{\oplus}$ commercial kit (BioMérieux ${ }^{\oplus}$ ). The HIV serology was based on the algorithm for screening for HIV infection used in the Central African Republic using two ELISA tests: Genscreen $^{\circledast}$ (HIV1/2-version 2; Biorad) and Vironostika ${ }^{\circledast}$ (HIV 1-uniform II plus O; BioMérieux ${ }^{\circledR}$ ). The parameters studied were epidemiological (age, sex, donor type, risk factors), clinical (signs of hepatocellular insufficiency and portal hypertension), biological (hepatitis B serology, HIV serology). Blood donors carrying HBsAg were entrusted to the hepatologist for clinical evaluation (search for signs of hepatocellular insufficiency, signs of portal hypertension and liver cha- 
racteristics), biological (transaminases, prothrombin levels) and morphological (abdominal ultrasound and upper digestive endoscopy looking for signs of portal hypertension) of chronic liver disease. The abdominal ultrasound was free, but other tests were the responsibility of the donors. Those who were infected with HIV benefited from the free pre-treatment assessment (hemogram, CD4 count, viral load of HIV, transaminase, creatininaemia, glycemia) and antiretroviral treatment by favoring the combination comprising Tenofovir and Emtricitabine which is associated either with Efavirenz is Lopinavir/ritonavir especially for co-infected donors HBV/HIV. Data analysis was done using Epi Info software version 2008 . The chi2 test was used for comparison with an $\alpha$ threshold $<0.05$.

\section{Results}

During the study period, we collected 850 blood donors (791 men and 59 women) among which 142 (16.7\%) were carriers of HBsAg and 77 (9.1\%) were infected with HIV. Among donors infected with HIV and HBV, we had 55 (6.5\%) blood donors co-infected with HBV/HIV (51 men and 4 women). The statistical analysis concerned only the mono-infected patients HBV and HIV in order to allow a better interpretation of the risk factors. Table 1 shows the distribution by sex.

The average age of HIV and HBV patients was 25.7 and 26.2 years, respectively. Figure 1 shows the distribution by age group.

Table 2 shows the different types of blood donors according to HBsAg status. Family donors and occasional donors were linked to the carriage of HBsAg.

The distribution of blood donors according to HIV status is presented in $\mathrm{Ta}$ ble 3. Only family donors were more exposed to HIV infection.

Risk factors for HIV infection and HBV are shown in Figure 2. The only risk factor found was protected or unprotected sex.

Table 1. Distribution by sex.

\begin{tabular}{ccccc}
\hline Sex & Male (\%) & Female (\%) & Total (\%) & p \\
\hline HBV positive & $84(10.6)$ & $3(0.3)$ & $87(100)$ & 0.00035 \\
VIH positive & $20(2.5)$ & $2(0.3)$ & $22(100)$ & 0.00017 \\
\hline
\end{tabular}

Table 2. Distribution of type of blood donors according to HBsAg status.

\begin{tabular}{cccc}
\hline Type of blood donor & HBsAg positive & HBsAg negative & p \\
Regular volunteers & $8(1 \%)$ & $225(28.3 \%)$ & - \\
Family & $56(7 \%)$ & $308(38.8 \%)$ & 0.0000 \\
Casual & $23(2.9 \%)$ & $175(22 \%)$ & 0.0010 \\
Total & $87(10.9 \%)$ & $708(89.1 \%)$ & \\
\hline
\end{tabular}


Table 3. Distribution of donor type according to the result of HIV serology.

\begin{tabular}{cccc}
\hline Type of blood donor & HIV positive & HIV negative & $\mathbf{p}$ \\
\hline Regular volunteers & $3(0.35 \%)$ & $250(31.4 \%)$ & - \\
Family & $16(2 \%)$ & $318(40 \%)$ & 0.0145 \\
Casual & $3(0.35 \%)$ & $205(25.7 \%)$ & 0.8096 \\
Total & $22(2.7 \%)$ & $773(97.3 \%)$ & \\
\hline
\end{tabular}

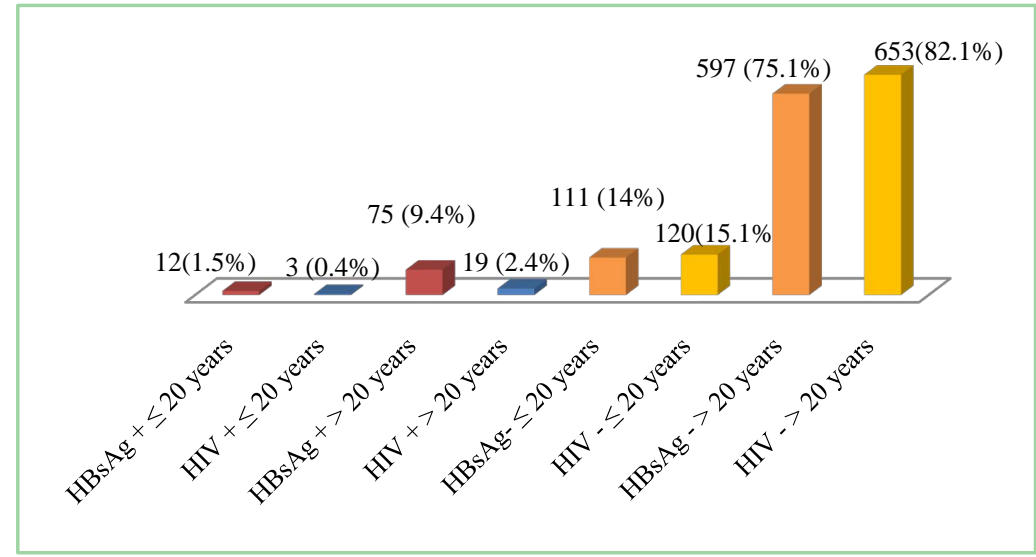

Figure 1. Distribution by age group. $\mathrm{p}=0.0003(\mathrm{VHB}), \mathrm{p}=0.0043(\mathrm{VIH})$.

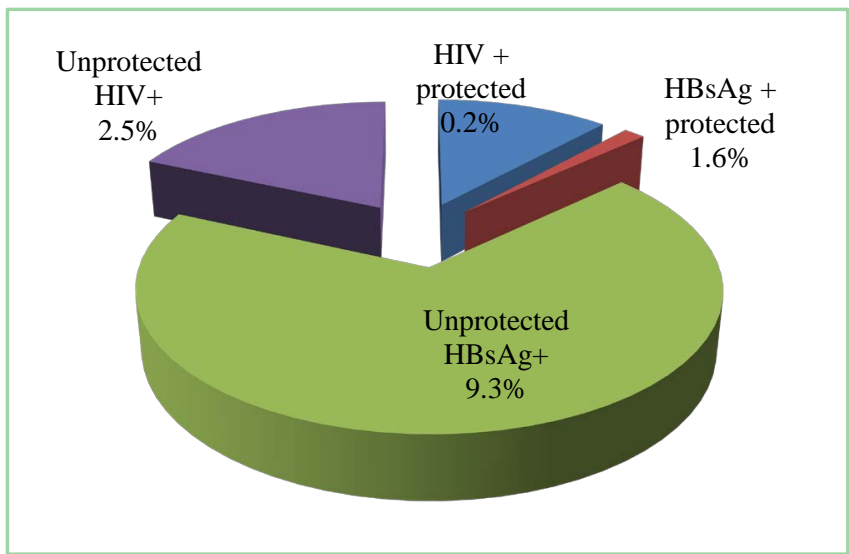

Figure 2. Type of sexual intercourse. $\mathrm{p}=0.0038(\mathrm{HIV}), \mathrm{p}=0.0017(\mathrm{HBV})$.

Physical examination of blood donors infected with HBV and those co-infected with HBV/HIV found no abnormality. The abdominal ultrasound found no liver abnormalities or signs of portal hypertension. No single HBV patient was able to get the viral load due to financial difficulty. The digestive endoscopy was not performed due to the absence of clinical and ultrasound signs of portal hypertension. HBV mono-infected blood donors could not be started on treatment because they could not perform viral load and non-invasive fibrosis tests. The average HIV viral load of HBV/HIV co-infected donors is $324,467 \mathrm{IU} / \mathrm{ml}$ with extremes ranging from 1456 to 1,354,230 IU/ml. All coinfected blood donors were put on treatment including Tenofovir-Emtricitabine-Efavirenz. They were 
reviewed in consultation at 1 month, then every 6 months for clinical, biological and morphological surveillance.

\section{Discussion}

However, our study has limitations, notably the lack of funding for the biological (HBV viral load, blood fibrosis tests) and morphological (fibroscan or liver biopsy puncture for histological analysis) evaluation of the stage of chronic hepatitis $B$ in seen to consider treatment. This management difficulty could only be overcome if the country had a national program to combat viral hepatitis. However, our study has the merit of showing decision-makers the extent of HBV infection in the population and the risk that patients run in the years to come, in particular the occurrence of complications such as cirrhosis and/or hepatocellular carcinoma. The prevalence of HBV and HIV infection in our study is higher than that observed in Yaoundé in Cameroon [8], in Kinshasa in the Democratic Republic of Congo [9], in Niamey in Niger [10], in Dar Es Salaam in Tanzania [11] and Burkina Faso [12]. However, it is lower than that reported by the authors in Osogo in Nigeria [13] and in Bamako in Mali [14]. Table 4 presents the prevalence of $\mathrm{HBV}$ and HIV infections in the different countries.

However, in Morocco, the prevalence of HBV infection is $3.97 \%$ and that of HIV infection $0.15 \%$ [15]. In Tripoli, Libya, the authors reported a prevalence of $\mathrm{HBV}$ infection at $2.6 \%$ for $\mathrm{HBV}$ and $0.4 \%$ for HIV [16]. These results confirm that the prevalence of HBV and even HIV infection is higher in sub-Saharan Africa. Also, the frequency of HBV infection is higher than that of HIV infection. The high frequency of HBV infection compared to HIV in our study could be explained by the absence of a national viral hepatitis control program. In the Central African Republic, as in other countries, there is a national HIV program, which provides awareness, testing and care for people living with HIV. People living with HIV treated when their viral load becomes low or undetectable are less contaminating. However, despite the existence of a national HIV program,

Table 4. Comparison of the prevalence of HBV and HIV infection in different African countries.

\begin{tabular}{ccc}
\hline Countries & HBV prevalence & HIV prevalence \\
\hline Our study & $16.7 \%$ & $9.1 \%$ \\
Yaoundé [8] & $12.6 \%$ & $0.2 \%$ \\
Kinshasa [9] & $5.9 \%$ & $3.8 \%$ \\
Niamey [10] & $15.4 \%$ & $1.62 \%$ \\
Dar Es Salam [11] & $8.8 \%$ & $3.8 \%$ \\
Burkina Faso [12] & $13.4 \%$ & $1.8 \%$ \\
Osogbo, Nigéria [13] & $19.9 \%$ & $3 \%$ \\
Ségou, Mali [14] & $18.1 \%$ & $2 \%$ \\
\hline
\end{tabular}


the frequency of HIV infection among our blood donors remains among the highest in sub-Saharan Africa. The male prevalence of HBV and HIV in our study has been reported by other African authors [8] [9] [10] [13] [14] [15] [16] [17]. It is linked to the fact that it is men who are often asked to donate blood, especially when it comes to compensatory donation, where the family sees only men first. The average age of donors infected with HBV is slightly higher than that of donors infected with HIV. The average age of blood donors infected with HBV in our study of 26.2 years and that of blood donors infected with HIV of 25.7 years is slightly lower than that reported by the authors in Cameroon, where the mean age was 28 years for HBV-infected blood donors and 26.3 years for HIV-infected blood donors [8]. HBV and HIV infection is more common in young adults in Africa. This is the sexually active population, probably not often using preventive measures. In our study, compensating family donors and occasional donors were the most infected with HBV and HIV. This observation was made by other authors [8] [9] [10] [11] [13] [14] [18]. The risk factor for HBV and HIV infection found in our donors was unprotected sex. Sexual transmission is one of the common modes of transmission of these two viruses. People should always be made aware of the use of condoms during casual sex.

\section{Conclusion}

The prevalence of HBV infection is higher than that of HIV among blood donors in Bangui. Hence the need to set up a national program to fight viral hepatitis, which will develop awareness-raising, screening, treatment and above all vaccination of subjects not infected with HBV.

\section{Conflicts of Interest}

The authors declare no conflicts of interest regarding the publication of this paper.

\section{References}

[1] WHO Global Hepatitis Report 2017 https://www.who.int/fr/news-room/detail/21-04-2017-new-hepatitis-data-highlightneed-for-urgent-global-response

[2] WHO HIV Report 2019. https://www.who.int/fr/news-room/fact-sheets/detail/hiv-aids

[3] Komas, N.P., Vickos, U., Hübschen, J.M., et al. (2013) Cross-Sectional Study of Hepatitis B Virus Infection in Rural Communities, Central African Republic. BMC Infectious Diseases, 13, Article No. 286. https://doi.org/10.1186/1471-2334-13-286 http://www.biomedcentral.com/1471-2334/13/286

[4] Komas, N.P., Baï-Sepou, S., Manirakiza, A., et al. (2010) The Prevalence of Hepatitis B Virus Markers in a Cohort of Students in Bangui, Central African Republic. BMC Infectious Diseases, 10, Article No. 226. https://doi.org/10.1186/1471-2334-10-226 http://www.biomedcentral.com/1471-2334/10/226

[5] Camengo Police, S.M., Longo, J.D.D., Mbeko Simaleko, M., et al. (2015) Hbs Antigen Prevalence in Female Sex Worker in Bangui. Annales de P Université de Bangui, série $D, 1,43-46$. 
[6] Camengo Police, S.M., Mbeko Simaleko, M., Mossoro-Kpindé, D.C., et al. (2013) HBsAg Prevalence among Homosexual Men in Bangui. Médecine d Afrique Noire, 60, 513-518.

[7] ONUSIDA 2019. https://www.unaids.org/fr/keywords/central-african-republic

[8] Ankouane, F., Noah Noah, D., Atangana, M.M., et al. (2016) Séroprévalence des virus des hépatites $\mathrm{B}$ et $\mathrm{C}$, du VIH-1/2 et de la syphilis chez les donneurs de sang de l'hôpital central de Yaoundé, région du centre, Cameroun. Transfusion Clinique et Biologique, 23, 72-77. https://doi.org/10.1016/j.tracli.2015.11.008

[9] Baleka, F., Pukuta, E., Lay, Y., et al. (2014) Prévalence et co-infection de VIH, VHC et VHB chez les donneurs de sang à Kinshasa, RDC. Congo Science, 2, 37-40.

[10] Mayaki, Z., Dardenne, N., Kabo, R., et al. (2013) Séroprévalence des marqueurs de l'infection chez les donneurs de sang à Niamey (Niger). Revue d' Epidémiologie et de Santé Publique, 61, 233-240. https://doi.org/10.1016/j.respe.2012.12.018

[11] Matee, M.I.N., Magesa, P.M. and Lyamuya, E.F. (2006) Seroprevalence of Human Immunodeficiency Virus, Hepatitis B and C Viruses and Syphilis Infections among Blood Donors at the Muhimbili National Hospital in Dar es Salaam, Tanzania. BMC Public Health, 6, Article No. 21. https://doi.org/10.1186/1471-2458-6-21

[12] Nagalo, B.M., Bisseye, C., Sanou, M., et al. (2012) Seroprevalence and Incidence of Transfusion-Transmitted Infectious Diseases among Blood Donors from Regional Blood Transfusion Centres in Burkina Faso, West Africa. Tropical Medecine International Health, 17, 247-253. https://doi.org/10.1111/j.1365-3156.2011.02902.x

[13] Opaleye Oluyinka, O., Tijani Busira, A., Zakariyahu Tawakalitu, O., et al. (2013) Prevalence of HBsAg and HIV among Blood Donors in Osogbo, Osun State, Nigeria. International Research Journal of Medicine and Medical Sciences, 1, 68-71.

[14] Traoré, H., Guitteye, H., Sangho, O., et al. (2019) Comparative Study of the Seroprevalence of HIV, HBV, HCV Infections among Blood Donors in Fixed and Mobile Collection. Revue Malienne d Infectiologie et de Microbiologie, 14, 52-57.

[15] Uwingabiye, J., Zahid, H., Unyendje, L., et al. (2016) Seroprevalence of Viral Markers among Blood Donors at the Blood Donor Center of Mohammed V Military Teaching Hospital of Rabat, Morocco. Pan African Medical Journal, 25, 185. https://doi.org/10.11604/pamj.2016.25.185.6266

[16] Khmmaj, A., Habas, E. and Azabi, M. (2010) Frequency of Hepatitis B, C, and HIV Viruses among Blood Donors in Libya. Libyan Journal of Medecine, 5, 5333. https://doi.org/10.3402/ljm.v5i0.5333

[17] Kra, O., N'Dri, N., Ehui, E., et al. (2007) Prevalence of HBs Antigen in Blood Donors in the Bouaké Regional Centre of Blood Transfusion in 2001. Bull Société Pathologie Exotique, 100, 127-129.

[18] Mongo-Onkouo, A., Dzia Lepfoudzou, A., Dinghat, O.M.Y., et al. (2019) Viral Hepatitis B: Seroprevalence and Genetic Diversity in Blood Donors North Congo. Open Journal of Gastroenterology, 9, 239-245. https://doi.org/10.4236/ojgas.2019.912027 